\title{
PELATIHAN TERAPI PERMAINAN KOOPERATIF SEBAGAI UPAYA MENGATASI TEMPER TANTRUM PADA ANAK PAUD DAN TK DI KECAMATAN AMBARAWA
}

\section{Cooperative Game Therapy Training As An Effort To Resolve Temper tantrum In Children In Early Childhood Education Program And Kindergarten District Of Ambarawa}

\author{
Mukhamad Musta' in ${ }^{1}$, Wulansari ${ }^{1}$, Fiktina Vifri Ismiriyam $^{1}$ \\ ${ }^{1}$ Prodi Diploma Tiga Keperawatan Fakultas Keperawatan Universitas Ngudi Waluyo Ungaran \\ Email: mukhamadmustain@gmail.com
}

\begin{abstract}
Abstrak
Temper trantum merupakan suatu luapan emosi yang tidak terkontrol pada anak, yang sering muncul pada anak tahap usia prasekolah. Minimnya pemahaman guru dan orangtua dalam menangani anak dengan temper tantrum dapat berakibat kurang baik pada perkembangan psikis anak. Pemberian informasi dan ketrampilan yang tepat tentang penanganan temper tantrum melalui terapi permainan kooperatif kepada murid, guru dan orangtua, dinilai sebagai salah satu upaya pencegahan atau meminimalkan munculnya temper tantrum. Tujuan kegiatan ini adalah tingginya partisipasi murid dalam permainan kooperatif dan peningkatan pengetahuan guru dan orangtua murid tentang penanganan anak dengan temper tantrum melalui permainan kooperatif. Metode yang digunakan adalah melakukan skrening pengetahuan tentang temper tantrum, selanjutnya pelaksanaan pelatihan permainan kooperatif sebanyak 2 kali pertemuan. Hasil dari kegiatan pengabdian ini adalah seluruh murid mengikuti permainan kooperatif. Selain itu pengetahuan peserta (guru dan orangtua), pada saat pretest didapatkan pengetahuan kurang $40 \%$, Cukup 35\% dan Baik 25\% dan saat posttest pengetahuan kurang 5\%, Cukup 35\% dan Baik 65\%. Dengan demikian dapat disimpulkan terdapat peningkatan pengetahuan peserta menjadi sebagian besar baik. Dengan demikian melalui pengabdian masyarakat para peserta diharapkan dapat melaksanakan upaya pencegahan temper tantrum dengan baik.
\end{abstract}

Kata kunci: Temper tantrum, usia pra sekolah, permainan kooperatif

\section{Abstract}

Temper Tantrum is an uncontrolled emotional outflow in children, which often occurs in preschool children. The lack of understanding of teachers and parents in dealing with children with temper tantrum can result in unfavorable to the child's psychological development. Provision of appropriate information and skills on handling temper tantrums through cooperative game therapy to students, teachers and parents, is considered as an effort to prevent or minimize the appearance of temper tantrums. The purpose of this activity is the high participation of students in cooperative games and increasing the knowledge of teachers and parents of students about handling children with temper tantrums through cooperative games. The method used is screening knowledge about temper tantrums, then the implementation of cooperative game training is 2 meetings. The result of this service activity is that all students participate in cooperative games. Besides the participants' knowledge (teachers and parents), at the time of the pretest knowledge was $40 \%$ less, 35\% Fair and 25\% Good and at the posttest knowledge was 5\% Less, 35\% Fair and $65 \%$ Good. Thus it can be concluded there is an increase in the knowledge of participants to a large extent good. Thus through community service, the participants are expected to be able to carry out prevention of Temper tantrum properly.

Keywords: Temper tantrum, pre-school age, cooperative games 


\section{PENDAHULUAN}

Temper tantrum adalah suatu luapan emosi yang meledak-ledak dan tidak terkontrol. Temper tantrum seringkali muncul pada anak suai 15 bulan hingga 6 tahun (Zaviera, 2008). Umumnya anak kecil lebih emosional daripada orang dewasa karena pada usia ini anak masih relatif muda dan belum dapat mengendalikan emosinya. Pada usia 2-4 tahun, karakteristik emosi anak muncul pada ledakan marahnya atau temper tantrum (Hurlock, 2000). Sikap yang ditunjukkan untuk menampilkan rasa tidak senangnya, anak melakukan tindakan yang berlebihan, misalnya menangis, menjeritjerit, melemparkan benda, berguling-guling, memukul ibunya atau aktivitas besar lainnya (Hurlock, 2000).

Pola asuh orang tua adalah pola perilaku orang tua yang diterapkan pada anak yang bersifat relatif dan konsisten dari waktu kewaktu. Pola perilaku ini dapat dirasakan oleh anak dari segi negative maupun positif (Edwards, 2006). Pada dasarnya pola asuh dapat diartikan seluruh cara perlakuan orang tua yang diterapkan pada anak. Banyak ahli mengatakan pengasuhan anak adalah bagian penting dan mendasar, menyiapkan anak untuk menjadi masyarakat yang baik. Terlihat bahwa pengasuhan anak menunjuk kepada pendidikan umum yang diterapkan. Pengasuhan terhadap anak berupa suatu proses interaksi antara orang tua dengan anak. Interaksi tersebut mencakup perawatan seperti dari mencukupi kebutuhan makan, mendorong keberhasilan dan melindungi, maupun mensosialisasi yaitu mengajarkan tingkah laku umum yang diterima oleh masyarakat (Jas \& Rahmadiana, 2004).

Pendampingan orang tua diwujudkan melalui pendidikan cara- cara orang tua dalam mendidik anaknya. Cara orang tua mendidik anaknya disebut sebagai pola pengasuhan. Dalam interaksinya dengan orang tua anak cenderung menggunakan cara-cara tertentu yang dianggap paling baik bagi anak. Disinilah letaknya terjadi beberapa perbedaan dalam pola asuh. Disuatu sisi orang tua harus bisa menentukan pola asuh apa yang tepat dalam mempertimbangkan kebutuhan dan situasi anak, disisi lain sebagai orang tua juga mempunyai keinginan dan harapan untuk membentuk anak menjadi seseorang yang dicita citakan yang tentunya lebih baik dari orang tuanya (Jas \& Rahmadiana, 2004).

Mengasuh anak dapat dilakukan orangtua yaitu dengan mengajak anak untuk bermain. Bermain adalah suatu aktivitas yang menyenangkan serta dapat menjadi sarana belajar bagi anak yang sekaligus menjadi suatu proses yang terjadi secara terus menerus dalam kehidupan dan mempunyai manfaat untuk merangsang perkembangan anak secara umum, membantu anak dalam bersosialisasi dengan teman sebayanya (Sekartini, 2011). Sedangkan menurut Adriana (2011), Bermain adalah salah satu stimulasi yang tepat bagi anak untuk merangsang daya pikir anak untuk mendayagunakan aspek emosional, sosial, dan fisiknya. Permainan kooperatif merupakan bagian dari permainan yang berfokus pada suatu keadaan dimana grup yang terdiri dari para pemain mengkoordinasikan aksi tindakan yang akan mereka lakukan melalui suatu komitmen tertentu. Tujuan dari permainan ini adalah mempelajari cara menjalankan atau mendorong kerjasama diantara agen-agen yang berkeinginan untuk bekerjasama. Dengan permainan kooperatif ini diharapkan anak mampu belajar bekerjasama, berdiskusi/ berkomunikasi sesama teman dan mengekspresikan emosi anak tersebut dengan baik.

Berdasarkan wawancara dengan orang tua yang ikut menunggui peserta didik, sebagian besar belum mengetahui apa itu temper tantrum, dan upaya 
pencegahannya. Mereka mengatakan saat temper tantrum muncul juga sering mengekang anak dan tidak sedikit yang memarahi anak dan ada yang memberikan pukulan fisik. Sedangkan wawancara dengan guru/ pengajar, menjelaskan bahwa kami masih minim pengetahuan tentang penanganan temper tantrum yang tepat dan apabila gejala tempertantrum muncul pada peserta didiknya maka guru cenderung untuk mengekang anak tersebut dengan harapan tidak mengganggu atau melukai anak yang lain.

\section{TUJUAN}

Tujuan pelatihan ini adalah:

1. Tingginya partisipasi murid dalam permainan kooperatif.

2. Peningkatan pengetahuan guru dan orangtua murid tentang penanganan anak dengan temper tantrum melalui permainan kooperatif.

\section{PELAKSANAAN}

A. Sasaran dan Metode kegiatan yang digunakan

Sasaran pengabdian adalah Murid, Guru/ Pengajar dan Orangtua wali murid dari PAUD Bunga Kartika dan TK Keluarga Panjang 3 Ambarawa. Metode yang digunakan melalui penyuluhan, ceramah dan Tanya jawab tentang tempertantrum, pelatihan dan simulasi/ demostrasi terapi permainan kooperatif bagi anak murid PAUD dan TK. Evaluasi dilakukan melalui pretest dan posttest dengan memberikan daftar pertanyaan untuk mengetahui pengetahuan peserta.

B. Waktu dan Tempat Kegiatan

Pengabdian masyarakat dilakukan di PAUD Bunga Kartika pada tanggal 12 dan 26 April, sedangkan kegiatan di TK Keluarga Panjang 3 dilaksanakan pada tanggal 18 dan 29 April 2019. Kegiatan di mulai jam 08.00 WIB hingga 10.00
WIB. Tempat kegiatan di Ruang kelas PAUD Bunga Kartika dan TK Keluarga Panjang 3 Ambarawa.

C. Materi

Materi yang disampaikan meliputi :

1. Pertumbuhan dan Perkembangan Anak Usia Pra Sekolah

2. Temper Tantrum pada Anak Usia Pra Sekolah

\section{HASIL DAN PEMBAHASAN HASIL}

Peserta pelatihan terdiri dari siswa PAUD dan TK, Guru PAUD dan TK serta orangtu dari siswa tersebut. Dimana siswa berjumlah 69 anak, Guru 5 orang dan orang tua sejumlah 35 orang yang hadir. Kegiatan simulasi permainan kooperatif diikuti oleh semua murid baik PAUD dan TK yang berjumlah 20 siswa PAUD dan 49 siswa TK, yang dapat dilihat pada tabel 1 berikut.

Tabel 1 Distribusi Frekuensi peserta didik PAUD dan TK

\begin{tabular}{clcc}
\hline No & Kelas & Frek & $\begin{array}{c}\text { Prosentase } \\
(\%)\end{array}$ \\
\hline 1 & PAUD & 20 & $29 \%$ \\
2 & TK & 49 & $71 \%$ \\
\hline & Total & 69 & $100 \%$ \\
\hline
\end{tabular}

Kegiatan pengabdian masyarakat pelatihan terapi permainan kooperatif (orangtua dan guru) diikuti oleh 40 peserta yang dijelaskan pada tabel 2 berikut.

Tabel 2 Distribusi Frekuensi peserta berdasarkan jenis kelamin

\begin{tabular}{clcc}
\hline No & $\begin{array}{c}\text { Jenis } \\
\text { Kelamin }\end{array}$ & Frek & $\begin{array}{c}\text { Prosentase } \\
(\%)\end{array}$ \\
\hline 1 & Laki- laki & 6 & $15 \%$ \\
2 & Perempuan & 34 & $85 \%$ \\
\hline & Total & 40 & $100 \%$ \\
\hline
\end{tabular}

Berdasarkan tabel 2 dapat disimpulkan bahwa peserta diikuti sebagian besar oleh perempuan. Hal ini karena para peserta 
adalah istri dari anggota TNI dan tinggal di komplek asrama Batalyon kavaleri 2 Ambarawa, disamping itu peserta didik sebagian besar dalam keseharian dirumah diasuh oleh ibunya.

\begin{tabular}{cccc} 
Tabel & 3 & \multicolumn{1}{c}{$\begin{array}{c}\text { Distribusi } \\
\text { berdasarkan pekerjaan }\end{array}$} & $\begin{array}{c}\text { Frekuensi } \\
\text { peserta }\end{array}$ \\
\hline No & Pekerjaan & Frekuensi & $\begin{array}{c}\text { Prosentase } \\
(\%)\end{array}$ \\
\hline 1 & Ibu & 22 & $55 \%$ \\
& Rumah & & \\
& Tangga & & $12.5 \%$ \\
2 & Swasta & 5 & $5 \%$ \\
3 & TNI & 2 & $2.5 \%$ \\
4 & Perawat & 1 & $12.5 \%$ \\
5 & Guru & 5 & $12.5 \%$ \\
6 & Lainnya & 5 & $100 \%$ \\
\hline & Total & 40 &
\end{tabular}

Berdasarkan tabel 3 dapat dijelaskan bahwa peserta kegiatan diikuti sebagian besar peserta dengan pekerjaan sebagai ibu rumah tangga. Hal ini karena para peserta adalah istri dari anggota TNI dan tinggal di komplek asrama Batalyon kavaleri 2 Ambarawa.

\begin{tabular}{|c|c|c|c|}
\hline Tabel & $\begin{array}{l}\text { 4. Distribusi } \\
\text { Berdasarkan } \\
\text { Pengetahuan } \\
\text { tantrum Sebe } \\
\text { Test). }\end{array}$ & $\begin{array}{l}\text { Frekue } \\
\text { Tent } \\
\text { lum } P\end{array}$ & 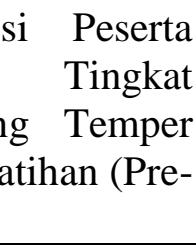 \\
\hline No & $\begin{array}{c}\text { Tingkat } \\
\text { Pengetahuan }\end{array}$ & Frek & $\begin{array}{c}\text { Prosentase } \\
(\%)\end{array}$ \\
\hline 1 & Kurang & 16 & $40 \%$ \\
\hline 2 & Cukup & 14 & $35 \%$ \\
\hline 3 & Baik & 10 & $25 \%$ \\
\hline & Total & 40 & $100 \%$ \\
\hline
\end{tabular}

Berdasarkan tabel 4 bahwa sebagian besar dari responden $(40 \%)$ memiliki pengetahuan yang kurang tentang temper tantrum pada saat sebelum pelatihan (pre-test). Hal ini kemungkinan masih minimnya paparan pengetahuan tentang temper tantrum dan masih kurangnya kegiatan seminar atau temu ilmiah tentang temper tantrum.

Tabel 5. Distribusi Frekuensi Peserta Berdasarkan Tingkat Pengetahuan Tentang Tempertantrum Setelah Pelatihan (Post-Test).

\begin{tabular}{clcc}
\hline No & $\begin{array}{c}\text { Tingkat } \\
\text { Pengetahuan }\end{array}$ & Frek & $\begin{array}{c}\text { Prosentase } \\
(\%)\end{array}$ \\
\hline 1 & Kurang & 2 & $5 \%$ \\
2 & Cukup & 12 & $30 \%$ \\
3 & Baik & 26 & $65 \%$ \\
\hline & Total & 40 & $100 \%$ \\
\hline
\end{tabular}

Berdasarkan tabel 5 bahwa sebagian besar dari responden $(65 \%)$ memiliki pengetahuan yang baik tentang tempertantrum pada saat setelah dilakukan pelatihan (post-test).

\section{PEMBAHASAN}

Pola asuh orang tua merupakan pola perilaku yang diajarkan kepada anaknya yang bersifat relatif dan konsisten dari waktu kewaktu yang dapat dirasakan oleh anak dari segi negative maupun positif (Edwards, 2006). Pola asuh diartikan seluruh cara perlakuan orang tua yang diterapkan pada anak. Banyak ahli mengatakan pengasuhan anak adalah bagian penting dan mendasar, menyiapkan anak untuk menjadi anggota masyarakat yang baik. Terlihat bahwa pengasuhan anak menunjuk kepada pendidikan umum yang diterapkan. Pengasuhan terhadap anak berupa suatu proses interaksi antara orang tua dengan anak. Interaksi tersebut mencakup perawatan seperti dari mencukupi kebutuhan makan, mendorong keberhasilan dan melindungi, maupun mensosialisasi yaitu mengajarkan tingkah laku umum yang diterima oleh masyarakat (Jas \& Rahmadiana, 2004). Pendampingan orang tua diwujudkan melalui pendidikan caracara orang tua dalam mendidik anaknya. Cara orang tua mendidik anaknya disebut 
sebagai pola pengasuhan. Dalam interaksinya dengan orang tua anak cenderung menggunakan cara-cara tertentu yang dianggap paling baik bagi anak. Disinilah letaknya terjadi beberapa perbedaan dalam pola asuh. Disuatu sisi orang tua harus bisa menentukan pola asuh apa yang tepat dalam mempertimbangkan kebutuhan dan situasi anak, disisi lain sebagai orang tua juga mempunyai keinginan dan harapan untuk membentuk anak menjadi seseorang yang dicita citakan yang tentunya lebih baik dari orang tuanya (Jas \& Rahmadiana, 2004). Berdasarkan hasil kajian sebagian besar dari responden 22 orang $(55 \%)$ adalah berprofesi sebagai Ibu Rumah Tangga. Orang tua (khususnya ibu) yang tidak bekerja mempunyai waktu banyak untuk selalu mendampingi anak untuk tumbuh dan berkembang secara optimal. Sementara ibu yang bekerja hanya sedikit mempunyai waktu untuk bisa berinteraksi dengan anak dibandingkan ibu yang tidak bekerja, tapi sebenarnya pendapat ini tidak sepenuhnya benar, ada ibu yang bekerja di luar rumah lebih sukses dalam mendidik anak-anak mereka dibanding ibu yang tidak bekerja.

Hasil kajian yang tertera di tabel 4 ditemukan bahwa tingkat pengetahuan peserta tentang temper tantrum sebelum pelatihan berada pada level kurang yaitu $40 \%$, cukup yaitu $35 \%$ dan baik $25 \%$. Hal ini kemungkinan masih minimnya pengetahuan dan kurangnya paparan tentang materi tempertantrum. Setelah dilakukan pelatihan yang dapat dilihat pada tabel 4, tingkat pengetahuan peserta berada pada level kurang sejumlah 5\% dan cukup menjadi $30 \%$ dan baik naik menjadi $65 \%$. Dengan demikian ada peningkatan pengetahuan setelah dilakukan pelatihan. Pengetahuan adalah hasil dari tahu yang terjadi setelah seseorang melakukan penginderaan terhadap suatu objek tertentu. Penginderaan terjadi melalui panca indera manusia, yakni indra penglihatan, pendengaran, penciuman, rasa dan raba, sebagian besar pengetahuan manusia diperoleh melalui mata dan telinga. Pengetahuan merupakan dominan yang sangat penting untuk terbentuknya tindakan seseorang (Notoatmodjo, 2003). Hasil penelitian Heriyanto (2015) dijelaskan bahwa tingkat pengetahuan ibu ada hubungannya dengan tingkat kejadian temper tantrum pada balita.

Pengetahuan orang tua akan berdampak pada cara orangtua mengasuh anaknya. Salah satu cara mengasuh anak yaitu dengan mengajak anak untuk bermain. Bermain adalah suatu aktivitas yang menyenangkan serta dapat menjadi sarana belajar bagi anak yang sekaligus menjadi suatu proses yang terjadi secara terus menerus dalam kehidupan dan mempunyai manfaat untuk merangsang perkembangan anak secara umum, membantu anak dalam bersosialisasi dengan teman sebayanya (Sekartini, 2011). Sedangkan menurut Adriana (2011), Bermain adalah salah satu stimulasi yang tepat bagi anak untuk merangsang daya pikir anak untuk mendayagunakan aspek emosional, sosial, dan fisiknya. Permainan kooperatif merupakan bagian dari permainan yang berfokus pada suatu keadaan dimana grup yang terdiri dari para pemain mengkoordinasikan aksi tindakan yang akan mereka lakukan melalui suatu komitmen tertentu. Tujuan dari permainan ini adalah mempelajari cara menjalankan atau mendorong kerjasama diantara agen-agen yang berkeinginan untuk bekerjasama. Dengan permainan kooperatif ini diharapkan anak mampu belajar bekerjasama, berdiskusi/ berkomunikasi sesama teman dan mengekspresikan emosi anak tersebut dengan baik. Dan akhirnya kejadian tempertantrum dapat diminimalkan dengan bermain kooperatif bersama temannya. Melalui pelatihan permainan kooperatif pada 
anak temper tantrum kepada guru dan wali murid akan semakin meningkatkan pemahaman guru dan orang tua sehingga penanganan anak yang mengalami temper tantrum dapat dilakukan dengan baik dan tepat.

\section{KESIMPULAN}

1. Seluruh siswa (100\%) baik PAUD dan TK mengikuti simulasi terapi permainan kooperatif

2. Klasifikasi pengetahuan sebelum pelatihan yaitu $40 \%$ Kurang, 35\% Cukup dan Baik 25\%

3. Klasifikasi pengetahuan setelah pelatihan yaitu 5\% Kurang, 30\% Cukup dan Baik 65\%

4. Terjadi peningkatan pengetahuan yang dikategorikan sebagian besar baik.

\section{SARAN}

Sebagai upaya meningkatkan pemahaman peserta tentang tempertantrum, perlu diadakan pemantauan secara berkala tentang kegiatan terapi permainan kooperatif pada semester selanjutnya.

\section{DAFTAR PUSTAKA}

Adriana, Dian, 2011. Tumbuh Kembang dan Therapy Bermain pada Anak. Jakarta: Salemba Medika.

Edwards, C. Drew, 2006. Ketika Anak Sulit Diatur: Panduan Bagi Para Orang Tua Untuk Mengubah Masalah Perilaku Anak. Bandung: PT Mizan Pustaka.
Hayes, E., 2003. Tantrum: Panduan memahami dan mengatasi ledakan emosi anak. Jakarta : Erlangga.

Hurlock, Elizabeth, B. 2000. Psikologi Perkembangan. Jakarta: Erlangga.

Heriyanto, H dan Farizal, J, 2015. Hubungan Tingkat Pengetahuan Ibu Terhadap Kejadian Temper Tantrum Pada Balita Di Kelurahan Talang Benih Wilayah Kerja Puskesmas Curup Tahun 2015. http://103.94.125.242/files/10.april/ Manuskrippublikasihendriheriyanto. pdf diunduh 1 Juli 2019.

Jas dan Rahmadiana, 2004. Mengkomunikasikan Moral Pada Anak. Jakarta : PT Elex Komputindo. Notoatmodjo, Soekidjo. 2003. Pendidikan Dan Perilaku Kesehatan. Rineka Cipta. Jakarta.

Rahayuningsih, SI, 2014. Strategi ibu mengatasi perilaku temper tantrum pada anak usia toddler di rumah susun keudah kota banda aceh. Idea Nursing Journal, ISSN: 2087-2879, Vol. V No. 12014.

Sekartini, Rini, 2011. Kumpulan Tips Pediatrik. Jakarta: Badan Penerbit Ikatan Dokter Anak Indonesia.

Surya, S., \& Robert, H, 2004. Panduan lengkap perawatan untuk bayi dan balita. Jakarta: Arcan.

Wulansari, (2017). Kenali Tanda-Tanda dan Bagaimana Cara Mengatasinya Dengan permainan kooperatif.

Zaviera, Ferdinand, 2008. Mengenali dan Memahami Tumbuh Kembang Anak Jogjakarta: Katahati. 